Juicios sobre la situación financiera

y el problema monetario en Chile

Para dor cumplimiento a su programa de trabajo. que la obliga a ocuparse en fodos los problemes de la culfura, sociales, económicos. que interesan a los habifantes de la República, Afenear se ha dirigido a las personas más versadas en las cuestiones de Hacienda y Economia. pidiéndoles se sirvan indicarnos sus opiniones acerca del actual problema monetario de Chile y la sifuación financiera general del pais.

Sólo hemos recibido respuestas de S. E.. el Presidente de la República, y de los señores Roberto Espinoza y Agustin Ross. El Excmo. scñor Alessandri nos ha reiterado las declaraciones que a este respecto ha hecho recientemente a la prensa, las que, junto con las opiniones de los distinguidos economistas señores Ross y Espinoza, insertamos a confinuación.

Arturo Alessandri

\title{
Actualidacles Económicas
}

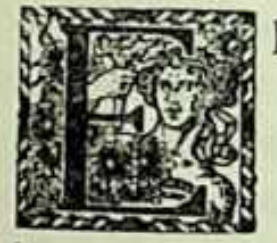

L cambio internacional se rige por la ley de la oferta y la demanda de letras. Cuando son muchos los que piden la mercaderia,-en este caso la libra esterlina._- ésta debe ser pagada a más alto precio. Por el contrario. si son muchos los que venden mercaderia.- - libras esterlinas representadas por letras de cambio,-la mercadería baja de precio y vale un número inferior de monedas nacionales.

En consecuencia, en materia de cambios internacionales, el problema está limitado a determinar la causa que produce y que rige la oferla y demanda de letras.

Son numerosos, variados y complejos los factores que influyen en la oferla y demanda de letras, o sea, en el mercado de los cambios.

La demanda de letras está representada por el servicio de las deudas fiscales en el extranjero, por las utilidades de las sociedades domiciliadas fuera del pais, por los capitales que emigran para las negociaciones de accionistas chilenos cuyo asiento se halla en el extranjero. por las mercaderias extranjeras que se compran e internan, y que deben ser pagadas en los países donde se producen. por los dineros que se remesan a los chilenos que viajan, y. en general. por la compra de letras de aquellos que en alguna forma y por alguna causa necesitan enviar fondos fuera del pais. 
Respecto de la oferta de letras. está representada por los capitales extranjeros que vienen al pais, por los artículos de exportación que se venden al extranjero y cuyo precio se paga en letras cobrables en otra plaza. y. en general, por los dineros que por cualquiera causa y circunstancia vienen al pais.

El factor especulación tiene en las fluctuaciones del cambio internacional una influencia mucho más poderosa y grande que la que se le atribuye. Nuestro mercado es relativamente pequeño y débil comparado con la inmensa fuerza compradora que representan algunos capitales radicados en el país, y, en consecuencia, disponiendo de dinero y de crédito, se pueden producir alteraciones y movimientos en la oferta y demanda de letras en la forma que se quiera, ocasionando asi fluctuaciones de alzas y bajas.

Es. en consecuencia, deber del Gobierno practicar una prolija investigación para ver hasta dónde la especulación produce alteraciones en la oferta y demanda de letras, o sea. en las mutaciones del cambio. Una investigación seria, en ejercicio de las facultades gubernativas, practicada en los Bancos y en las Bolsas de Comercio. nos dará una estadistica exacta en orden a cuales son las letras que obedecen a operaciones comerciales efectivas, y cuáles son las letras que no responden a una efectiva necesidad. y que. por lo tanto. representan factores de especulación que hacen al pais el inmenso daño de contribuir a la depreciación de su moneda.

Se dice con insistencia que algunas fuertes instituciones de crédito, empeñadas en obstaculizar la implantación del Banco Central.- que se ve venir con la nueva organización del Congreso,- - procuran por todos los medios posibles producir una situación comercial grave y delicada en el mercado de los cambios, para oponerla como un dique insalvable a la implantación del Banco Central, y el Gobierno está en la obligación de investigar y esclarecer por todos los medios a su alcance si el hecho es efectivo o nó.

Entre las funciones del Banco Central, ocupa lugar preferente el desempeñar. sin costo alguno para el Estado, las propiamente bancarias, que hoy corren a cargo del Ministerio de Hacienda y que se ejecutan por intermedio de algunos bancos particulares. He dicho en muchas ocasiones que las utilidades ingresadas a los bancos particulares como consecuencia de las operaciones bancarias fiscales, - que mañana ejecutará graluitamente el Banco Central._- representan sumas fabulosas.

Estas verdaderas monstruosidades. que en ningún otro país del mundo en que los intereses creados no tengan el imperio y la luerza que tienen entre nosotros. habrian sido toleradas. justifican la importancia que para nosolros tiene la implantación del Banco Central y explican el temor de las instifuciones particulares, a quienes. con el establecimiento de este Banco. se succionaría una de sus más poderosas $y$ principales fuentes de entradas.

El Gobierno necesita saber si son ciertos los rumores de que se está produciendo un pánico intencionalmente para hacer imposible la implantación de una medida salvadora que hace tanto tiempo reclama la opinión. Chile va siendo ya uno de los pocos paises en el mundo que no cuentan con_ese organismo regulador del crédito y de las operaciones financieras del Estado.

La estadística de exportación y venta de salitre revela que en el trimestre 
Diciembre-Enero-Febrero las ventas alcanzaron la enorme suma de ochocientas mil toneladas. lo que representa, más o menos, ocho millones de libras esterlinas entradas al pais. El trimestre actual Marzo-Abril-Mayo representa una venta minima que no llega a setenta mil toneladas, debido a la estación climatérica de Europa, a la depreciación del franco francés. cuyo valor comprador ha disminuido considerablemente y a otras causas que no es del caso enumerar. En este trimestre el salitre vendido representa setecientas mil libras esterlinas, contra ocho millones que representó este producto en el trimestre anterior.

En consecuencia, el salitre que se venderá en Marzo. Abril y Mayo representa una entrada menor de siete millones trescientas mil libras esterlinas respecto a lo que se vendió en Diciembre. Enero y Febrero. De Junio para adelante se restablecerá la normalidad en las ventas y se dejará sentir forzosamente la correspondiente mejoria en el cambio, el cual, es evidente. está influenciado por los números anteriores. Estas expectativas en el mercado auguran un mejoramiento en el cambio que nos autorizan para afirmar que no son justas las alarmas y el pesimismo con que muchos juzgan estas materias.

La preocupación más constante del Gobierno en estos momentos es la de desarrollar un plan definitivo de orden y método en nuestras finanzas. A esto dedica actualmente sus energias en la misma forma en que abordó el problema internacional. la ley relativa a la marina mercante, el impuesto a la renta y las reformas constitucionales. legales y reglamentarias que han introducido una transformación completa en nuestro régimen institucional.

El Gobierno tiene en estudio diversas y numerosas medidas que someterá a la deliberación del Congreso el primero de Junio. y. entre otras. considera con especial y detenida atención la consolidación de la deuda externa. operación que nos dará recursos para saldar todo el déficit, existente en la Hacienda Pública y que podria rebajar el servicio de ella en treinta o cuarenta millones de pesos.

Muy grande sería la importancia de reducir en tal forma el servicio de nuestra deuda y la consiguiente remesa anual de fondos al extranjero por esa cuantiosa suma. Pero todo eso no es posible hacerlo en un día.

Los acontecimientos hablarán con la elocuencia de los hechos consumados. y antes de mucho, capacitado el Gobierno para obrar sin obstáculos, sabrá responder a la conlianza que en él ha depositado la mayoría inmensa del país. 